\title{
$\Delta$ F508 mutation screening of healthy individuals from two populations in Espírito Santo State, Brazil
}

\author{
A.M. Lanes ${ }^{1}$, L.S. Louro' , D.P. Ventorim ${ }^{3}$, E. Stur ${ }^{3}$, F.M. Garcia ${ }^{3}$, \\ L.P. Agostini ${ }^{3}$, L.N.R. Alves ${ }^{3}$, R.S. Reis ${ }^{3}$, I.D. Louro ${ }^{3}$ and R.S. Dettogni ${ }^{3}$ \\ ${ }^{1}$ The Masters School, Dobbs Ferry, NY, USA \\ ${ }^{2}$ Escola São Domingos, Vitória, ES, Brasil \\ ${ }^{3}$ Núcleo de Genética Humana e Molecular, Departamento de Ciências Biológicas, \\ Centro de Ciências Humanas e Naturais, Universidade Federal do Espírito Santo, \\ Vitória, ES, Brasil
}

Corresponding author: R.S. Dettogni

E-mail: rasdett@yahoo.com.br

Genet. Mol. Res. 15 (4): gmr15049387

Received September 28, 2016

Accepted November 11, 2016

Published December 19, 2016

DOI http://dx.doi.org/10.4238/gmr15049387

Copyright (C) 2016 The Authors. This is an open-access article distributed under the terms of the Creative Commons Attribution ShareAlike (CC BY-SA) 4.0 License.

\begin{abstract}
The $\Delta$ F508 mutation is the most common cause of cystic fibrosis and its prevalence varies worldwide. For instance, up to 20 -fold variations in its frequency have been recorded across different areas of Brazil. This study aimed to compare the distribution of $\Delta \mathrm{F} 508$ among healthy individuals of admixed Portuguese descent from Espírito Santo (ES), a state in Southeastern Brazil, to that in a subpopulation of Pomeranian descent, considered to be an isolated group in which the European gene pool has been preserved, living in Santa Maria do Jetibá (also in ES). We found this mutation to be present at a frequency of $0.81 \%$ among the Pomeranian group, and $0 \%$ in the general ES population. No genetic differentiation was noted between the two populations
\end{abstract}


examined $\left(F_{\mathrm{ST}}=0.004\right)$, and these frequencies were found to be similar to those estimated in other states of Southeastern Brazil. Although the population of Santa Maria de Jetibá has retained Pomeranian traits, such as language, fair skin, and eye color, to date, there is no evidence of inbreeding in this group $\left(F_{\text {IS }}=-0.004\right)$. Screening healthy individuals for the $\Delta \mathrm{F} 508$ mutation can facilitate genetic counseling for cystic fibrosis, as well as inform evolutionary and population studies.

Key words: $\Delta$ F508; Screening; Cystic fibrosis; Espírito Santo-Brazil

\section{INTRODUCTION}

Cystic fibrosis $(\mathrm{CF})$ is an autosomal recessive disorder (Online Mendelian Inheritance in Man No. 219700) involving deficient transport of $\mathrm{Cl}^{-}$ions in the apical membranes of epithelial cells. It affects all ethnic groups, but is more common among Caucasians. This disease arises due to mutations in the gene encoding the CF transmembrane conductance regulator (CFTR) protein, resulting in dysregulated transportation of $\mathrm{Cl}^{-}$and $\mathrm{Na}^{+}$ions, the concentrations of which are elevated in the sweat of individuals presenting with this condition (Kerem et al., 1989; Riordan et al., 1989; Rommens et al., 1989; Welsh et al., 2001). A common CFTR mutation comprising a 3-bp deletion in exon 10 causes the loss of the phenylalanine residue at position 508 (p.Phe508del or $\Delta$ F508) in the amino acid sequence (Kerem et al., 1989; Riordan et al., 1989; Rommens et al., 1989). CF is one of the most common genetic diseases affecting people of European descent, with an incidence of approximately one in every 2500 live births, and a carrier frequency of around one in 25 (Welsh et al., 1995). Interestingly, the frequency of this disease varies globally. In a survey carried out by Raskin et al. (2008), Brazilians of European origin accounted for $54 \%$ of the total population of Brazil, the remaining proportion being composed of African and Native American ethnic groups (Faucz et al., 2010). In the South and Southeast regions of this country, an average CF incidence of one in every 7576 births has been reported (Raskin and Fauez, 2001; Raskin et al., 2008), decreasing from the former to the latter, as more people of European ancestry live in South Brazil (Raskin et al., 2008). The results of Raskin et al. (2008) suggest that CF incidence differs by up to 20 times across areas of Brazil, and that the average mutation carrier frequency in the total population is $2.3 \%$. Although the frequency of the $\Delta \mathrm{F} 508$ mutation has been estimated in some states in Southeastern Brazil (Okay et al., 2005), Espírito Santo (ES) has not been extensively surveyed yet. A previous study based in ES, a state colonized by Europeans, demonstrated that the frequency of $\Delta F 508$ heterozygote individuals was low among the healthy population (Rabbi-Bortolini et al., 1998).

The city of Santa Maria de Jetibá, situated in the mountainous region of ES, was heavily colonized by immigrants from Pomerania, now part of northern Germany and Poland. This community has remained largely culturally closed up to the present day (Bahia, 2001). Because of this distinctive population characteristic and a lack of data concerning the prevalence of $\Delta \mathrm{F} 508$ in ES, we aimed to estimate $\Delta \mathrm{F} 508$ frequency among healthy volunteers from this state, including individuals of Pomeranian origin. Due to the population admixture present in Brazil, it is believed that the European genetic profile of ES has changed over time, explaining observed reductions in $\triangle F 508$ heterozygosity. Such changes may not have occurred in the Pomeranian population of this state, which may therefore exhibit a heterozygote frequency typical of a European population.

Genetics and Molecular Research 15 (4): gmr15049387 


\section{MATERIAL AND METHODS}

This study was approved by the Ethics Committee of Health Sciences Center Universidade Federal do Espírito Santo (No. 190/11).

\section{Study sample}

The study sample consisted of 246 healthy subjects, including 123 representatives of the general population of ES and 123 individuals of Pomeranian descent, the latter resident in Santa Maria de Jetibá, ES. All study participants gave their informed consent. Peripheral blood samples $(5 \mathrm{~mL})$ were collected from healthy subjects of the wider ES population in tubes containing ethylenediaminetetraacetic acid, while three to five drops of peripheral blood from healthy Pomeranian volunteers were placed on FTA Elute Cards (Whatman, Clifton, NJ, USA). Genomic DNA was isolated using phenol/chloroform extraction or according to the FTA Elute Card manufacturer recommendations.

\section{Genotyping}

Presence of the $\Delta \mathrm{F} 508$ mutation was determined by polymerase chain reaction (PCR) followed by detection of amplification products using silver-stained polyacrylamide gel electrophoresis. The wild-type allele yielded a single 98-bp fragment, whereas the $\Delta \mathrm{F} 508$ allele resulted in a 95-bp product (i.e., lacking $3 \mathrm{bp}$ ). PCRs contained the following: $10 \mathrm{ng}$ genomic DNA, $0.4 \mathrm{mM}$ each primer (sense CFF: 5'-GTTTTCCTGGATTATGCCTGGGCA-3' and antisense CFR: 5'-GTTGGCATGCTTTGATGACGTTTC-3'; Okay et al., 2005), $1.5 \mathrm{mM}$ $\mathrm{MgCl}_{2}$, and 2.5 U Taq DNA polymerase (Invitrogen, São Paulo, SP, Brazil). Amplification was performed in a Veriti thermal cycler (Applied Biosystems, Foster City, CA, USA) with a cycling program of 35 cycles of $45 \mathrm{~s}$ at $94^{\circ} \mathrm{C}, 45 \mathrm{~s}$ at $65^{\circ} \mathrm{C}$, and $45 \mathrm{~s}$ at $72^{\circ} \mathrm{C}$.

\section{Statistical analysis}

Allele and genotype frequencies were determined by direct counting. Data were analyzed by the Fisher exact test in GraphPad Prism v7.01 (GraphPad Software, La Jolla, CA, USA). P values $<0.05$ were considered statistically significant. Other statistical analyses were performed using the Arlequin software v3.11 (Excoffier et al., 2007).

\section{RESULTS}

\section{Description of the study sample}

The average ages in the Pomeranian and general ES population groups were 40.4 and 33.4 years, respectively. Of the individuals in these respective groups, 41.5 and $42.3 \%$ were female.

\section{Genotyping}

None of the 123 healthy individuals representing the general ES population carried the $\Delta \mathrm{F} 508$ mutation. Among those of Pomeranian origin, the frequency of this mutation was $0.81 \%$ (two heterozygous subjects; Table 1). Genotyping results are shown in Figure 1.

Genetics and Molecular Research 15 (4): gmr15049387 
Table 1. Screening for the $\Delta$ F508 mutation in two populations of Espirito Santo State (ES), Brazil.

\begin{tabular}{l|c|c}
\hline Genotype or allele & General ES population $(\mathrm{N}=123 ;$ number of alleles $=246)$ & Population of Pomeranian descent $(\mathrm{N}=123 ;$ number of alleles $=246)$ \\
\hline $\mathrm{N} / \mathrm{N}$ & $100 \%(123)$ & $98.37 \%(121)$ \\
\hline $\mathrm{N} / \mathrm{DF}$ & $0 \%(0)$ & $1.63 \%(2)$ \\
\hline $\mathrm{DF} / \mathrm{DF}$ & $0 \%(0)$ & $0 \%(0)$ \\
\hline $\mathrm{N}$ & $100 \%(246)$ & $99.19 \%(244)$ \\
\hline $\mathrm{DF}$ & $0 \%(0)$ & $0.81 \%(2)$ \\
\hline & & $\mathrm{P}=0.5^{\mathrm{a}}$ \\
\hline
\end{tabular}

aP value from the Fisher exact test.

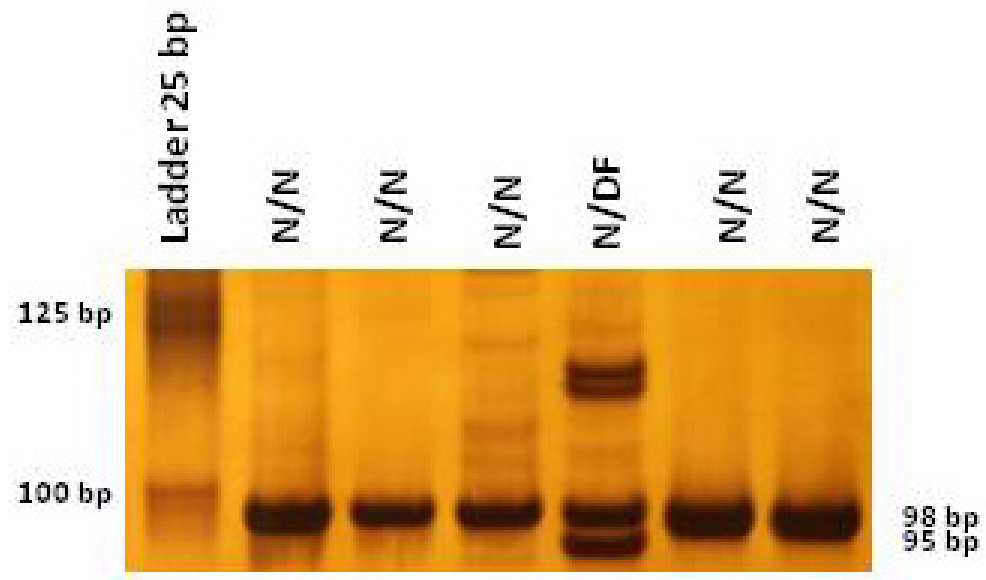

Figure 1. Detection of the $\Delta \mathrm{F} 508$ mutation by polymerase chain reaction followed by electrophoresis on a $15 \%$ polyacrylamide gel. $\mathrm{N} / \mathrm{N}=$ normal homozygous (one 98-bp fragment), N/DF = heterozygous (98 and 95-bp fragments). Molecular weight is indicated by a 25-bp ladder (Invitrogen, Carlsbad, CA, USA), the 100 and 125-bp fragments of which are shown.

\section{Statistical analysis at the population level}

The frequency of $\triangle \mathrm{F} 508$ in the two ES populations is shown in Table 1, and a comparison with that in the populations of other Southeastern Brazilian states [Minas Gerais (MG) and São Paulo (SP)] is shown in Table 2. There was no statistically significant difference between these groups.

Table 2. Frequency of the $\Delta \mathrm{F} 508$ mutation among healthy individuals of Southeastern Brazil.

\begin{tabular}{|c|c|c|c|c|c|}
\hline \multirow{3}{*}{$\begin{array}{l}\text { Population } \\
\text { São Paulo (SP) }\end{array}$} & \multirow{3}{*}{$\begin{array}{c}\text { Number of alleles } \\
1022\end{array}$} & \multirow{3}{*}{$\begin{array}{c}\Delta \mathrm{F} 508 \text { frequency }(\%) \\
0.29\end{array}$} & \multirow{3}{*}{$\begin{array}{l}\text { Reference } \\
\text { Raskin et al. (2008) }\end{array}$} & \multicolumn{2}{|c|}{ P value/statistically significant (Fisher's exact test) } \\
\hline & & & & SP/PP & $0.25 / \mathrm{No}$ \\
\hline & & & & SP/ES & $>0.99 / \mathrm{No}$ \\
\hline \multirow[t]{2}{*}{ Minas Gerais (MG) } & \multirow[t]{2}{*}{1232} & \multirow[t]{2}{*}{0.33} & \multirow[t]{2}{*}{ Raskin et al. (2008) } & MG/PP & $0.26 / \mathrm{No}$ \\
\hline & & & & MG/ES & $>0.99 / \mathrm{No}$ \\
\hline
\end{tabular}

$\mathrm{PP}=$ population of Pomeranian descent in Espírito Santo State; ES = general population of Espírito Santo State.

A comparison of $\triangle \mathrm{F} 508$ frequencies among $\mathrm{CF}$ patients in various European regions and Brazil is shown in Table 3 . The chi-square test revealed a statistically significant difference between these populations $(\mathrm{P}<0.0001)$.

Genetics and Molecular Research 15 (4): gmr15049387 
Table 3. Comparison of $\Delta \mathrm{F} 508$ frequencies among cystic fibrosis patients in various European regions and Brazil.

\begin{tabular}{l|l|l}
\hline Population & $\Delta \mathrm{F} 508$ frequency $(\%)$ & Reference \\
\hline Poland & 62.4 & Sobczyńska-Tomaszewska et al. (2013) \\
\hline Germany & 71.8 & Lucotte and Hazout (1995) \\
\hline Europe & 66.8 & Estivill et al. (1997) \\
\hline Portugal & 44.5 & Estivill et al. (1997) \\
\hline Brazil & 47.7 & Cabello et al. (1999) \\
\hline & $\mathrm{P}<0.0001^{*}$ & \\
\hline
\end{tabular}

*Statistically significant (chi-square test).

For the population of Pomeranian origin, expected $\left(H_{\mathrm{E}}\right)$ and observed heterozygosity $\left(H_{\mathrm{O}}\right)$ was found to be 0.0162 and 0.0163 , respectively. Using Wright's F-statistics, the inbreeding coefficient $\left(F_{\text {IS }}\right)$ and fixation index $\left(F_{\mathrm{ST}}\right)$ were calculated. The $F_{\text {IS }}$ was -0.004 , indicating that despite the minimal difference between $H_{\mathrm{E}}$ and $H_{\mathrm{O}}$, heterozygosity was higher than expected, implying no inbreeding in this population. No heterozygotes were identified in the general ES population. The Pomeranian population was in Hardy-Weinberg equilibrium (chi-square $=0.01, \mathrm{P}=0.93$ ), but this calculation could not be performed for the general ES population, since only the wild-type allele was detected. The $F_{\mathrm{ST}}$ was 0.004 , indicating low genetic differentiation and high gene flow between the two ES populations. Data concerning population genetics are shown in Table 4.

Table 4. Analysis of the population genetics of the Pomeranian study group based on Wright's F-statistics.

\begin{tabular}{l|c}
\hline Analysis & Pomeranian population \\
\hline Expected heterozygosity & 0.0162 \\
\hline Observed heterozygosity & 0.0163 \\
\hline HWE (chi-square/P) & $0.01 / 0.93$ \\
\hline$F_{\text {IS }}$ & -0.004 \\
\hline$F_{\text {ST }}$ compared with general ES population) & 0.004 \\
\hline
\end{tabular}

$F_{\text {IS }}=$ inbreeding coefficient; $F_{\text {ST }}=$ fixation index; HWE = Hardy-Weinberg equilibrium.

\section{DISCUSSION}

The population of Brazil is known to be mixed and heterogeneous, composed of Native American, African, and European groups. Consequently, high levels of variation in allelic frequencies are evident (Faucz et al., 2010). ES represents 1.8\% of the Brazilian population (Brazilian Institute of Geography and Statistics, 2010). In the nineteenth century, this state had large Native American and African populations, as well as a considerable number of European immigrants having arrived after the Portuguese colonization (Saletto, 2000). In 1872 and 1873, approximately 4000 Pomeranians immigrated to ES, and people of Pomeranian descent now comprise the majority of the population of this state's mountainous region. They have retained their culture, including a distinct Pomeranian language. In this study, we analyzed the prevalence of the $\Delta \mathrm{F} 508$ mutation, the main sequence variant responsible for $\mathrm{CF}$, among healthy individuals from the general ES population and the Pomeranian population residing in Santa Maria de Jetibá, ES.

This mutation was not identified in the general ES population, and was present at a frequency of $0.81 \%$ in the Pomeranian group. $\Delta \mathrm{F} 508$ homozygous individuals exhibit the classical clinical manifestations of CF. In the heterozygous state, $\Delta F 508$ can cause a number of 
respiratory disorders (Dahl et al., 2001; Wang et al., 2005; Maurya et al., 2012); however, the vast majority of carriers are asymptomatic. There is a certain degree of speculation regarding heterozygote selective advantages in conditions such as cholera, typhoid fever, tuberculosis, and lactose intolerance (Baxter et al., 1988; Rodman and Zamudio, 1991; MacKenzie, 2006; Modiano et al., 2007), given that this mutation prevents dehydration. A $\Delta$ F508 frequency of $0.02 \%$ has been reported in Europe, likely due to such heterozygote advantages (Modiano et al., 2007), the existence of which highlights the relevance of determining $\Delta$ F508 prevalence not only among patients diagnosed with $\mathrm{CF}$, but also in the wider, healthy population. Nonetheless, given that $\triangle \mathrm{F} 508$ is not the only mutation that causes $\mathrm{CF}$, the screening of other such sequence variations is also advisable.

Data concerning heterozygote frequencies are important for the genetic counseling of individuals in particular populations and the establishment of effective public health policies. Santa Maria de Jetibá represents the third largest Pomeranian population in the world, and is known to have maintained its cultural identity (Bahia, 2001; Domingues et al., 2006).

In this study, we studied the frequency of $\Delta \mathrm{F} 508$ in two ES populations. In the general population, its prevalence was found to be similar to that in most other Brazilian regions surveyed. This supports the hypothesis that mixing of allelic profiles that are more common in Europe with those of other groups present in this country has resulted in a lower $\Delta F 508$ frequency. This process evidently also occurred in the general population of ES, where Native Americans, Africans, and Europeans have interbred to the extent that $\Delta \mathrm{F} 508$ is rarely observed. The $F_{\mathrm{ST}}$ value, a measure of the difference between the genetic structures of populations, was calculated to be 0.004 , confirming that the two populations have interbred freely (panmixis).

We propose that the observed frequency of $\Delta \mathrm{F} 508$ among the Pomeranian population examined was due to greater preservation of the European gene pool. The $F_{\text {IS }}$ statistic, which measures the likelihood that two given alleles are identical by descent, had a negative value $(-0.004)$, indicating that inbreeding has not occurred within this population. To reiterate, we confirm that there is gene flow between the residents of Santa Maria de Jetibá and individuals from other locations within the state. Thus, people of Pomeranian descent in ES initially considered of "pure European origin" also demonstrate a certain degree of genetic admixture. Therefore, we suggest that our results justify considering the Pomeranian population together with the general ES population in future studies.

\section{CONCLUSIONS}

In this study, we observed similar frequencies of the $\Delta \mathrm{F} 508$ mutation, associated with European descent, in the general ES population and the Pomeranian population of this state. Moreover, the prevalence of this mutation in these groups was comparable to that recorded in other Southeastern Brazilian states. In addition, we demonstrated evidence of gene flow between the two populations, previously considered isolated from each other. We are aware that our results should be considered with caution, due to the technical obstacles inherent to this type of study, such as the difficulties encountered when determining the optimal criteria to differentiate individuals of unmixed European descent from those with an admixed background.

Ascertaining the frequency of mutant alleles among healthy individuals may be beneficial for CF genetic counseling in the population studied. As CF is clearly underdiagnosed throughout Brazil, the data presented in this work contribute to an estimation of the incidence

Genetics and Molecular Research 15 (4): gmr15049387 
of this disease in different states, and to improving the quality of genetic counseling and management of disorders associated with $\Delta \mathrm{F} 508$ heterozygosity.

\title{
Conflicts of interest
}

The authors declare no conflict of interest.

\section{ACKNOWLEDGMENTS}

\author{
Research supported by FAPES.
}

\section{REFERENCES}

Bahia J (2001). A "lei da vida": confirmação, evasão escolar e reinvenção da identidade entre os pomeranos. Educ. Pesq. 27: 69-82.

Baxter PS, Goldhill J, Hardcastle J, Hardcastle PT, et al. (1988). Accounting for cystic fibrosis. Nature 335: 211. http:// dx.doi.org/10.1038/335211a0

Brazilian Institute of Geography and Statistics (IBGE) (2010). Population Census 2010. Available at http://censo2010. ibge.gov.br.

Cabello GM, Moreira AF, Horovitz D, Correia P, et al. (1999). Cystic fibrosis: low frequency of DF508 mutation in 2 population samples from Rio de Janeiro, Brazil. Hum. Biol. 71: 189-196.

Dahl M, Nordestgaard BG, Lange P and Tybjaerg-Hansen A (2001). Fifteen-year follow-up of pulmonary function in individuals heterozygous for the cystic fibrosis phenylalanine-508 deletion. J. Allergy Clin. Immunol. 107: 818-823. http://dx.doi.org/10.1067/mai.2001.114117

Domingues RB, Aquino CC, Santos JG, da Silva AL, et al. (2006). Prevalence and impact of headache and migraine among Pomeranians in Espirito Santo, Brazil. Arq. Neuropsiquiatr. 64: 954-957. http://dx.doi.org/10.1590/S0004$\underline{282 X 2006000600013}$

Estivill X, Bancells C and Ramos C; The Biomed CF Mutation Analysis Consortium (1997). Geographic distribution and regional origin of 272 cystic fibrosis mutations in European populations. Hum. Mutat. 10: 135-154. http://dx.doi. org/10.1002/(SICI)1098-1004(1997)10:2<135::AID-HUMU6>3.0.CO;2-J

Excoffier L, Laval G and Schneider S (2007). Arlequin (version 3.0): an integrated software package for population genetics data analysis. Evol. Bioinform. Online 1: 47-50.

Faucz FR, Souza DA, Olandoski M and Raskin S (2010). CFTR allelic heterogeneity in Brazil: historical and geographical perspectives and implications for screening and counseling for cystic fibrosis in this country. J. Hum. Genet. 55: 7176. http://dx.doi.org/10.1038/jhg.2009.123

Kerem B, Rommens JM, Buchanan JA, Markiewicz D, et al. (1989). Identification of the cystic fibrosis gene: genetic analysis. Science 245: 1073-1080. http://dx.doi.org/10.1126/science.2570460

Lucotte G and Hazout S (1995). Geographic and ethnic distribution of the more frequent cystic fibrosis mutations in Europe show that a founder effect is apparent for several mutant alleles. Hum. Biol. 67: 561-576.

MacKenzie D (2006). Cystic fibrosis gene protects against tuberculosis. New Sci. Available at https://www.newscientist. com/article/dn10013-cystic-fibrosis-gene-protects-against-tuberculosis.

Maurya N, Awasthi S and Dixit P (2012). Association of CFTR gene mutation with bronchial asthma. Indian J. Med. Res. 135: 469-478.

Modiano G, Ciminelli BM and Pignatti PF (2007). Cystic fibrosis and lactase persistence: a possible correlation. Eur. J. Hum. Genet. 15: 255-259. http://dx.doi.org/10.1038/sj.ejhg.5201749

Okay TS, Oliveira WP, Raiz-Júnior R, Rodrigues JC, et al. (2005). Frequency of the deltaF508 mutation in 108 cystic fibrosis patients in Sao Paulo: comparison with reported Brazilian data. Clinics (Sao Paulo) 60: 131-134. http:// dx.doi.org/10.1590/S1807-59322005000200009

Rabbi-Bortolini E, Bernardino AL, Lopes AL, Ferri AS, et al. (1998). Sweat electrolyte and cystic fibrosis mutation analysis allows early diagnosis in Brazilian children with clinical signs compatible with cystic fibrosis. Am. J. Med. Genet. 76: 288-290. http://dx.doi.org/10.1002/(SICI)1096-8628(19980401)76:4<288::AID-AJMG2>3.0.CO;2-M

Raskin S and Fauez FR (2001). Aspectos genéticos da fibrose cística. In: Doenças genéticas em pediatria (Carakushansky G, ed.). 1st edn. Guanabara Koogan, São Paulo, 227-241.

Genetics and Molecular Research 15 (4): gmr15049387 
Raskin S, Pereira-Ferrari L, Reis FC, Abreu F, et al. (2008). Incidence of cystic fibrosis in five different states of Brazil as determined by screening of p.F508del, mutation at the CFTR gene in newborns and patients. J. Cyst. Fibros. 7: 15-22. http://dx.doi.org/10.1016/j.jcf.2007.03.006

Riordan JR, Rommens JM, Kerem B, Alon N, et al. (1989). Identification of the cystic fibrosis gene: cloning and characterization of complementary DNA. Science 245: 1066-1073. http://dx.doi.org/10.1126/science.2475911

Rodman DM and Zamudio S (1991). The cystic fibrosis heterozygote--advantage in surviving cholera? Med. Hypotheses 36: 253-258. http://dx.doi.org/10.1016/0306-9877(91)90144-N

Rommens JM, Iannuzzi MC, Kerem B, Drumm ML, et al. (1989). Identification of the cystic fibrosis gene: chromosome walking and jumping. Science 245: 1059-1065. http://dx.doi.org/10.1126/science.2772657

Saletto N (2000). Sobre a composição étnica da população capixaba. Dimensões -Revista de História da Universidade Federal do Espirito Santo 11: 11-364.

Sobczyńska-Tomaszewska A, Ołtarzewski M, Czerska K, Wertheim-Tysarowska K, et al.; NBS CF working group (2013). Newborn screening for cystic fibrosis: Polish 4 years' experience with CFTR sequencing strategy. Eur. J. Hum. Genet. 21: 391-396. http://dx.doi.org/10.1038/ejhg.2012.180

Wang X, Kim J, McWilliams R and Cutting GR (2005). Increased prevalence of chronic rhinosinusitis in carriers of a cystic fibrosis mutation. Arch. Otolaryngol. Head Neck Surg. 131: 237-240. http://dx.doi.org/10.1001/archotol.131.3.237

Welsh MJ, Tsui LC, Boat TF and Beaudet AL (1995). Cystic fibrosis. In: The metabolic and molecular bases of inherited disease (Scriver CR, Beaudet AL, Sly WS and Valle D, eds.). 7th edn. McGraw-Hill, New York, 3799-3876.

Welsh MJ, Ramsey BW, Accurso F and Cutting GR (2001). Cystic fibrosis. In: The metabolic and molecular bases of inherited disease (Scriver CR, Beaudet AL, Sly WS and Valle D, eds.). 8th edn. McGraw-Hill, New York, 51215188.

Genetics and Molecular Research 15 (4): gmr15049387 